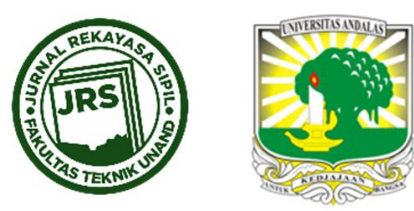

\title{
KUAT TEKAN BETON SELF COMPACTING CONCRETE (SCC) MENGGUNAKAN PASIR BESI PADA PESISIR PANTAI KECAMATAN WAPLAU
}

\author{
ERWIN SYAIFUL WAGOLA ${ }^{1^{*}}$, EDDY AGUS MUHARYANTO ${ }^{1}$ \\ ${ }^{1}$ Program Studi Teknik Sipil, Fakultas Teknik. Universitas Iqra Buru. Maluku, Indonesia \\ *Corresponding author: $\varangle$ wagolauniqbu@gmail.com
}

Naskah diterima : 15 Desember 2020. Disetujui: 31 Juli 2021

\begin{abstract}
ABSTRAK
Beton Self Compacting Concrete (SCC) mulai dikembangkan di Jepang sejak tahun 1983, beton ini dapat memadat secara mandiri dengan slump yang cukup tinggi. Self Compacting Concrete (SCC) mempunyai sifat flowability yang tinggi sehingga mampu mengalir, memenuhi bekisting, dan mencapai kepadatan tertingginya sendiri. Penelitian ini bertujuan untuk menganalisis karakteristik dari pasir besi pada pesisir pantai Kecamatan Waplau Kabupaten Buru, Provinsi Maluku dan menganalisis kuat tekan beton Self Compacting Concrete yang menggunakan pasir besi pada pesisir pantai Kecamatan Waplau, Kabupaten Buru, Provinsi Maluku, sebagai pengganti agregat halus. Metode yang digunakan pada penelitian ini yaitu metode eksperimental atau pengujian langsung di laboratorium, Hasil pemeriksaan karakteristik pasir besi memperlihatkan bahwa modulus kehalusan sebesar 2,55 nilai ini masuk kategori pasir agak kasar, berat jenis semu sebesar 4,47, berat jenis kering sebesar 4,35, dan berat jenis SSD adalah sebesar 4,39, kemudian penyerapan air sebesar 1,20 \%, dan Send Equivalen dari pasir besi diperoleh sebesar 97\%, Kuat tekan rata-rata beton Self Compacting Concrete dengan variasi campuran beton $100 \%$ pasir besi untuk umur beton 3, 7 dan 28 hari adalah 13,46 MPa, 19,23 MPa dan 28,27 MPa. Kuat tekan rata-rata beton SCC dengan variasi campuran beton $50 \%$ pasir besi dan 50\% pasir sungai untuk umur beton 3, 7, dan 28 hari adalah 14,42 MPa, 20,57 MPa dan 30,96 MPa. Sehingga berdasarkan hasil penelitian tersebut terlihat bahwa pemanfaatan pasir besi dalam campuran beton Self Compacting Concrete sangat berkontribusi terhadap kenaikan kuat tekan beton Self Compacting Concrete. Karena itu disarankan agar pemanfaatan sumber daya pasir besi di Kecamatan Waplau, Kabupaten Buru, Provinsi Maluku ini harus dimanfaatkan penggunaanya guna pengembangan teknologi beton khususnya dalam pengambangan beton Self Compacting Concrete (SCC).
\end{abstract}

Kata kunci : pasir besi, kuat tekan beton, campuran beton, Self Compacting Concrete

\section{PENDAHULUAN}

Kecamatan Waplau berada di Kabupaten Buru, Provinsi Maluku. Wilayah Kecamatan Waplau umumnya berada di pesisir pantai, panjang garis pantai $\pm 40 \mathrm{~km}$, dengan tipikal pantai berpasir dan berbatu, salah satu wilayah pantai di kecamatan ini memiliki keunikan 
dan kekayaan hayati yang tidak dimiliki oleh wilayah pantai lain di Kecamatan Waplau pada khususnya dan Kabupaten Buru pada umumnya. Wilayah pantai yang dimaksud adalah wilayah pantai Desa Waprea dimana wilayah ini memiliki jenis pasir yang mengandung biji besi yang cukup melimpah. Karena memiliki kandungan biji besi yang cukup banyak maka dirasa perlu untuk dilakukan penelitian dengan memanfaatkan atau menggunakan pasir besi ini dalam campuran beton Self Compacting Concrete atau beton SCC sehingga dapat diketahui seberapa besar kontribusi yang dapat diberikan oleh pasir besi ini terhadap penigkatan kuat tekan beton Self Compacting Concrete. Adapun gambaran lokasi pengambilan sampel pasir besi diperlihatkan pada Gambar 1.

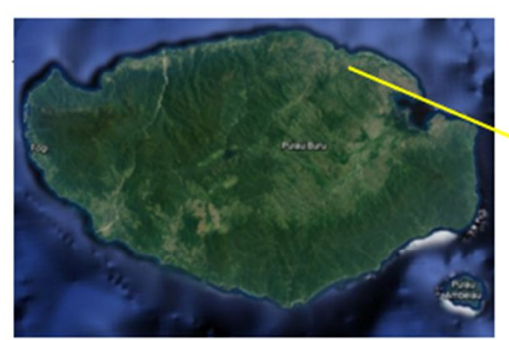

(a) Peta Pulau Buru Provinsi Maluku

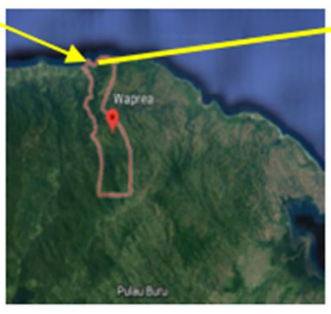

(b). Titik Quary Pasir Besi

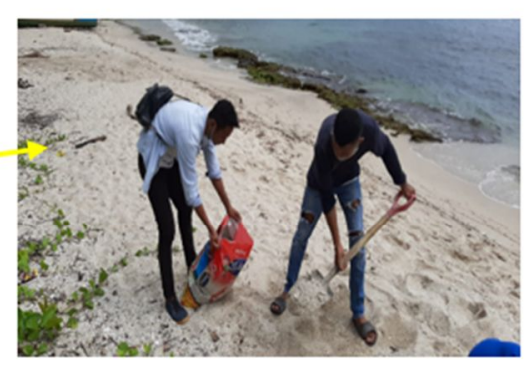

(c) Lokasi Pantai Desa Waprea

Gambar 1. Lokasi Quary Pengambilan Sampel Pasir Besi

Pekerjaan pemadatan atau vibrasi adalah pekerjaan yang penting dalam pekerjaan konstruksi beton, terutama untuk pekerjaan beton bertulang. Namun dalam pelaksanaan pekerjaan beton sering ditemukan kendala yaitu kesulitan untuk melakukan pemadatan. Alat vibrator atau pemadat tidak bisa menjangkau dengan baik karena jarak tulangan yang rapat. Pemadatan menjadi tidak baik dan bisa menghasilkan beton dengan kualitas rendah, seperti keropos, permeabilitas tinggi, dan terjadi pemisahan material pada beton (Korua et al., 2019).

Beton memadat sendiri yaitu self compacting concrete (SCC), merupakan konsep inovatif untuk menghasilkan beton yang dapat "mengalir" dengan mudah tanpa perlu dipadatkan, namun tetap kohesif dan bermutu tinggi (Miza et al., 2019). Pengecoran beton SCC tidak membutuhkan pemadatan sehingga mempunyai keuntungan mengurangi jumlah tenaga kerja, memperpendek waktu pengecoran, dan mengurangi kebisingan akibat penggunaan alat pemadat (Nicolaas \& Slat, 2019).

Ngudiyono dkk (2021) mengemukakan beberapa keuntungan dari pemakaian self compacting concrete (SCC). Pemakaian beton SCC bisa mengurangi durasi konstruksi dan mengurangi besarnya upah. Pemadatan beton yang bertujuan untuk mendapat tingkat kepadatan optimum bisa dieleminir, disamping mengurangi kebisingan juga meningkatkan kepadatan pada bagian yang sulit dijangkau dan secara umum meningkatkan mutu beton (Ngudiyono et al., 2021).

Penelitian ini memanfaatkan penggunaan pasir besi sebagai material subtitusi dalam campuran beton self compacting concrete (SCC) seperti yang dilakukan menurut Astuti (2017) yaitu dengan memanfaatkan penggunaan Fly Ash pada campuran beton self compacting concrete (SCC). Pemanfaatan admixture pada beton Self Compacting Concrete juga dipakai guna memperbaiki kerusakan yang dapat terjadi pada umur beton. Penggunaan 
fiber pada produksi beton Self Compacting Concrete dapat meminimalisir terjadinya crack serta menaikan homogenitas beton dengan cara meminimalisir terjadinya bleeding. Namun demikian penambahan serbuk bata dan limbah fiber pada pembuatan beton Self Compacting Concrete (SCC) dapat meningkatkan flowability dan workability beton SCC ditunjukkan dengan peningkatan nilai slump flow (Safarizki, 2017).

Dalam memproduksi beton yang dikategorikan sebagai Self Compacting Concrete, komposisi agregat yang digunakan harus diperhatikan, mengingat semakin besar prosentase agregat halus akan meningkatkatkan flowability beton, tetapi jika terlalu banyak akan mengurangi kuat tekan beton. Begitu sebaliknya, jika terlalu banyak prosentase agreagat kasar akan memperbesar resiko segregasi dan mengurangi flowability dari beton (Nicolaas \& Slat, 2019).

Terdapat beberapa penelitian terdahulu tentang beton SCC. Miza et. al. (2019) meneliti tentang High Strength Self Compacting Concrete (HSSCC), dimana hasil penelitian menunjukkan bahwa uji kuat tekan yang didapat pada umur 28 hari pada persentase $0 \%$ adalah $57,62 \mathrm{MPa}$, persentase $1,5 \%$ yaitu $47,18 \mathrm{MPa}$, persentase $1,6 \%$ yaitu $51,95 \mathrm{MPa}$ dan persentase $1,7 \%$ yaitu $49,12 \mathrm{MPa}$. Uji kuat tarik lentur terbesar dengan umur 28 hari didapatkan pada persentase beton mix 1,7\% dengan nilai 7,71 MPa.

Nicolaas \& Slat (2019) dalam penelitian mereka melakukan identifikasi pemanfaatan beton pemadatan mandiri (self compacting concrete) sebagai balok struktur dengan menggunakan agregat lokal. Hasil penelitian mereka menunjukkan bahwa, komposisi campuran yang menghasilkan kuat tekan optimum yaitu komposisi $\mathrm{C} 1$, dimana perbandingan penggunaan agregat kasar dengan agregat halus adalah 50\% : 50\%. Mereka memperoleh nilai kuat tekan optimum pada umur 28 hari sebesar 30,36 MPa, sementara kuat lentur sebesar 3,94 MPa. Lebih lanjut mereka merumuskan hubungan kuat tekan dan kuat lentur SCC, dengan persamaan $r=0,76 \sqrt{ } f c$; menunjukkna koefisien $\mathrm{k}$ untuk beton $\operatorname{SCC}(\mathrm{k}=0,76)$ lebih besar dibandingkan untuk beton normal menurut SNI 03-2847-2002 $(k=0,7)$.

Astuti et. al (2018) meneliti tentang Pengaruh Perbedaan Bentuk Penampang Spesimen Terhadap Hubungan Tegangan dan regangan pada beton high volume fly ash Self compacting concrete(HVFA-SCC). Hasil penelitian mereka menghasilkan beton HVFA SCC pada umur 28 hari memiliki kuat desak yang lebih rendah dibandingkan dengan beton normal, rata-rata penurunan kekuatan beton HVFA SCC adalah sebesar $27 \%$. Beton normal dengan profil penampang segiempat memiliki kuat desak terendah, sementara kenaikan sebesar $23 \%$ untuk penampang segienam dan $41 \%$ untuk penampang lingkaran. Untuk beton HVFA-SCC, penampang segiempat memiliki kuat desak terendah dengan kenaikan sebesar $43 \%$ untuk segienam dan 52\% untuk lingkaran. Penelitian Astuti dkk ini juga menghasilkan temuan bahwa nilai modulus elastisitas rata-rata pada beton HVFA-SCC lebih kecil dibandingkan beton normal, beton HVFA-SCC sebesar 9578,47 Mpa dan 13774,44 MPa untuk beton normal.

Berdasarkan uraian pada latar belakang yang menjadi masalah pada penelitian ini adalah bagaimana karakteristik dari pasir besi yang berada di pesisir pantai Desa Waprea, Kecamatan Waplau Kabupaten Buru dan apakah pasir besi pada pesisir pantai Desa Waprea ini dapat meningkatkan kuat tekan beton khususnya beton Self Compacting Concrete(SCC). Tujuan dari penelitian ini adalah untuk menganalisis karakteristik pasir besi pada pesisir pantai Desa Waprea, Kecamatan Waplau, Kabupaten Buru, Provinsi Maluku dan mengetahui kontribusi pasir besi terhadap kenaikan kuat tekan beton Self Compacting Concrete (SCC). 


\section{METODOLOGI PENELITIAN}

Adapun alur dan tahapan penelitian ini (Gambar 2) dimulai dengan penyiapan material (Badan Standarisasi Nasional, 2011), kemudian dilanjutkan dengan pengujian material penyusun beton SelfCompacting Concrete, berupa pemerikasaan karakteristik agregat kasar, dan agregat halus, setelah dilakukan pemeriksaan karakteristik material dan memenuhi spesifikasi yang diisyaratkan oleh ASTM berikutnya dilakukan mix design campuran beton Self Compacting Concrete berdasarkan SNI 03-2847-2000. Kemudian setelah mix design campuran beton memenuhi kriteria kelecakan melalui uji nilai Slump Flow, selanjutnya dilakukan pembuatan benda uji dimana benda uji berupa slinder beton dibuat dalam dua variasi komposisi campuran beton Self Compacting Concrete, setelah benda uji yang dibuat mengeras selanjutnya dilakukan perawatan atau curing dengan merendam beton kedalam bak perendaman selama 28 hari. Setelah direndam beton kemudian diangakat dan diuji kuat tekannya berdasarkan umur perendaman yaitu pengujian dilakukan untuk umur beton 3,7 dan 28 hari. Hasil dari pengujian diolah datanya untuk kemudian dianalisa guna diketahui seberapa besar kontribusi penggunaan pasir besi dalam campuran beton Self Compacting Concrete terhadap kenaikan kuat tekan beton Self Compacting Concrete (SCC).

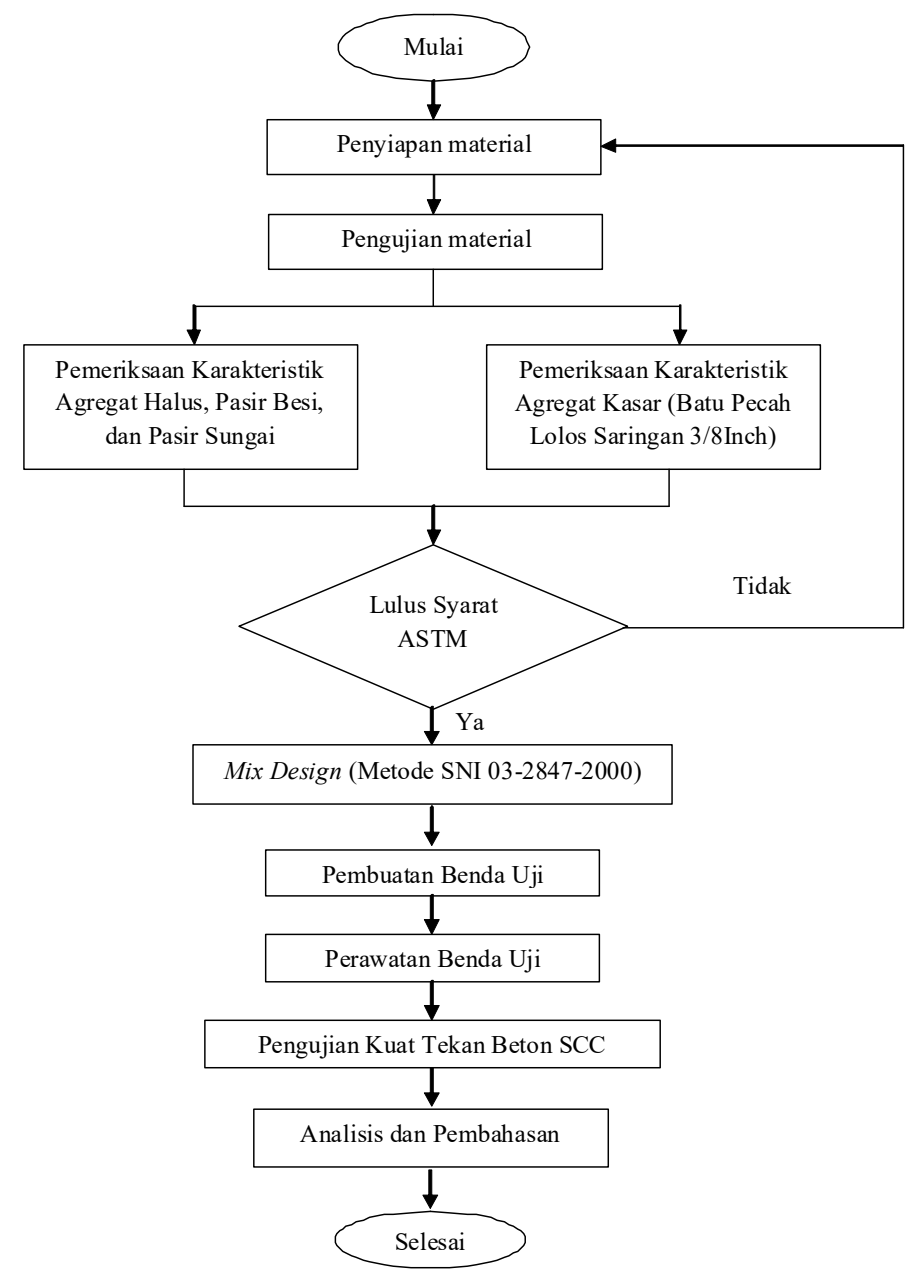

Gambar 2. Tahapan penelitian 


\subsection{Bahan Pembuatan Beton SCC}

Adapun material yang akan dipakai dalam pembuatan beton SCC yang memakai pasir besi sebagai pengganti agregat halus pada eksperimen ini ialah sebagai berikut:

1. Semen yang digunakan merupakan Portland Composit Cement (PCC).

2. Agregat kasar yang dipakai diambil di quary di Kecamatan Waplau Kabupaten Buru yang lolos saringan $3 / 8 \mathrm{Inch}$ atau diameter sebesar $20 \mathrm{~mm}$.

3. Agregat halus yang dipakai adalah pasir sungai dari quary sunagai Waeapo Kabupaten Buru dan Pasir Besi dari Pantai Waplau Kabupaten Buru. Adapun pasir besi yang digunkan dalam penelitian ini ditunjukkan oleh Gambar 3.

4. Air yang dipakai dalam campuran SCC adalah air yang layak minum.

5. Superplasticizer sebagai bahan admixture adalah Sika Viscorete 3115.

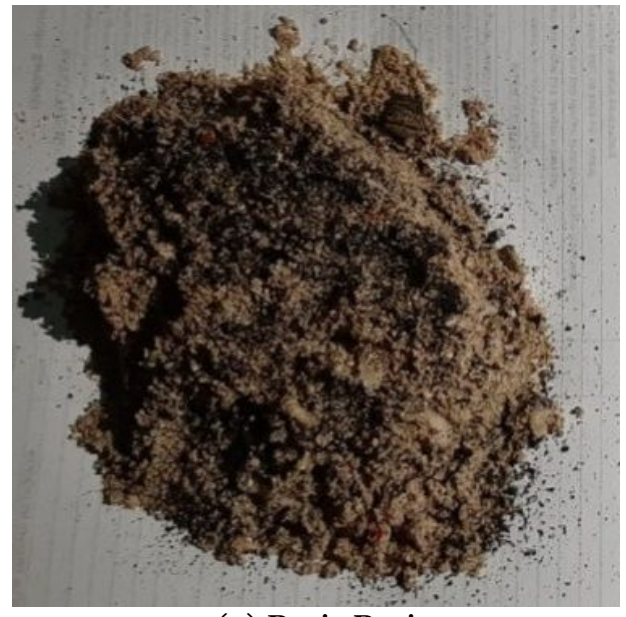

(a) Pasir Besi

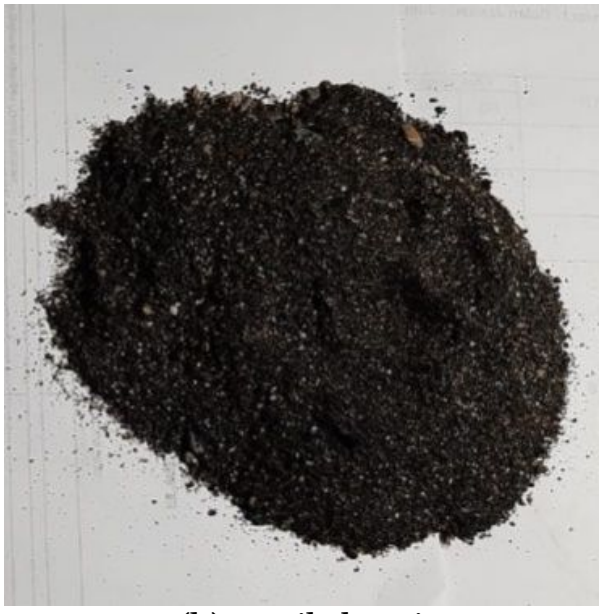

(b) Partikel Besi

Gambar 3. Pasir pantai yang digunakan dalam penelitian

\subsection{Pengujian Karakteritik Agregat}

Pemeriksaan data agregat dalam penelitian ini dilaksanakan mengacu pada standar of the American Society for Testing Material (ASTM, 2003).

\subsection{Penetapan Komposisi Campuran Beton SCC}

Beton memadat sendiri atau (SCC) adalah pengembangan teknologi dari beton,, dimana rancangan campuran beton SCC juga mengalami perubahan-perubahan dari campuran sebelumnya. Mengingat dengan adanya admixture seperti Superplasticizer dan Retarder, maka sedikit akan memberikan pengaruh pada hasil dari campuran beton SCC. Untuk memperoleh campuran beton SCC yang optimal dalam penelitian ini, maka dilakukan penyesuain-penyesuaian denagn tetap menggunakan acuan pada metode campuran beton berdasarkan SNI-03-2834-2000 tentang Tata Cara Pembuatan Rencana Campuran Beton Normal (Badan Standarisasi Nasional, 2000) sebagai dasar.

\subsection{Pengujian Slump Flow}

Pengujian nilai slump flow dilaksanakan menurut peraturan ASTM C143M - 03, Metode pelaksanaan slump flow, pengujian slump flow dimaksudkan untuk memperoleh konsistensi atau kekentalan dari pada campuran beton SCC. 


\subsection{Pengujian Kuat Tekan}

Uji kuat tekan dilaksanakan dengan menggunakan alat "Concrete Compression Testing Machine"yang memiliki kapasitas $1500 \mathrm{kN}$, pengujian ini dilaksanakan berdasarkan SK SNI 03-1974-1990 (Badan Standardisasi Nasional, 1990). Untuk perhitungan kuat tekan dilakukan sesuai dengan SK SNI 03-1974-1990 yang memberikan rumus kuat tekan beton sebagai berikut:

$$
\begin{array}{ll}
f^{\prime} c=\frac{P}{A} & \\
\text { Dimana }: & \text { Kuat Tekan (Mpa) } \\
\text { f'c } \quad \text { Keban maksimum yang terjadi }(\mathrm{N}) \\
\mathrm{P} \quad \text { Luas penampang yang dibebani }(\mathrm{mm} 2) \\
\mathrm{A} \quad
\end{array}
$$

\section{HASIL DAN PEMBAHASAN}

Pengujian kekuatan beton SCC dalam penelitian ini dilaksanakan setelah umur perawatan beton mencapai umur 3, 7, dan 28 hari. Hal ini dimaksudkan agar dapat diukur kenaikan kuat tekan beton pada setiap umur perawatan. Pelaksanaan pengujian dilakukan terhadap dua variasi campuran beon dengan subtitusi penggunaan pasir besi sebagai pengganti agregat halus.

\begin{tabular}{|c|c|c|c|c|c|c|c|c|c|}
\hline \multirow{3}{*}{ No. } & \multirow{3}{*}{ Jenis Pengujian } & \multirow{3}{*}{ Sat. } & \multicolumn{3}{|c|}{ Hasil Pengujian } & \multicolumn{4}{|c|}{ Spesifikasi } \\
\hline & & & \multirow{2}{*}{$\begin{array}{c}\text { Pasir } \\
\text { Besi }\end{array}$} & \multirow{2}{*}{$\begin{array}{l}\text { Pasir } \\
\text { Sungai }\end{array}$} & \multirow{2}{*}{$\begin{array}{l}\text { Batu } \\
\text { Pecah }\end{array}$} & \multicolumn{2}{|c|}{ Pasir } & \multicolumn{2}{|c|}{ Kerikil } \\
\hline & & & & & & Min & $\operatorname{Max}$ & Min & $\operatorname{Max}$ \\
\hline 1 & Modulus Kehalusan & $\%$ & 2.55 & 2.53 & 6.66 & 1.5 & 3.8 & 6.0 & 7.1 \\
\hline 2 & Berat Jenis Semu & - & 4.47 & 2.65 & 2.83 & 2.5 & - & 2.5 & - \\
\hline 3 & Berat Jenis Kering & - & 4.35 & 2.50 & 2.63 & 2.5 & - & 2.5 & - \\
\hline 4 & Berat Jenis SSD & - & 4.39 & 2.57 & 2.70 & 2.5 & - & 2.5 & - \\
\hline 5 & Water Absorbsi & $\%$ & 1.20 & 2.48 & 2.79 & 1 & 3 & 1 & 3 \\
\hline 6 & Send Equivalen & $\%$ & 97 & 85 & 96 & 50 & - & 50 & - \\
\hline
\end{tabular}

\subsection{Pemeriksaan Karakteristik Agregat}

Adapun rekapitulasi hasil pemerikasaan karakteristik agregat di laboratorium diperlihatkan pada Tabel 1 Di bawah ini.

Tabel 1. Rekapitulasi Hasil Pemerikasaan Karakteristik Agregat

Pada di atas terlihat bahwa hasil pemeriksaan karakteristik dari pada material pembuatan beton Self Compacting Concrete (SCC), semuanya telah memenuhi standar spesifikasi oleh ASTM, dimana semua jenis pengujian yang dilakukan di Laboratorium telah memenuhi atau masuk pada standar yang diisyaratkan.

\subsection{Komposisi Campuran Beton SCC}

Rancangan campuran beton SCC pada riset ini mengacu pada metode SNI-03-2847-2000, dimana jumlah batu pecah dan pasir yang dipakai adalah 40\%:60\%, dengan dua variasi campuran beton yaitu dengan pemakaian komposisi $100 \%$ pasir besi dan $50 \%$ pasir besi ditambah $50 \%$ pasir sungai, FAS yang digunakan adalah 0,45 dengan penambahan 
Superplasticizer. Adapun hasil rancangan campuran beton SCC dalam satuan Kg dari dua variasi pemakaian pasir besi dapat dilihat pada Tabel 2 .

Tabel 2. Hasil Mix Design Beton SCC untuk $1 \mathrm{~m}^{3}$ Beton

\begin{tabular}{llcccccc}
\hline \multirow{2}{*}{ No. } & \multirow{2}{*}{ Jenis Pengujian } & $\begin{array}{c}\text { Pasir } \\
\text { Besi }\end{array}$ & $\begin{array}{c}\text { Pasir } \\
\text { Sungai }\end{array}$ & $\begin{array}{c}\text { Batu } \\
\text { Pecah }\end{array}$ & Semen & Air & $\begin{array}{c}\text { Superplastici } \\
\text { zer }\end{array}$ \\
\hline 1 & $\begin{array}{l}\text { Beton SCC - PB } \\
\text { (f'c }=25 \mathrm{MPa})\end{array}$ & 674,20 & - & 971,15 & 422,22 & 192,42 & 4,22 \\
\hline 2 & $\begin{array}{l}\text { Beton SCC-PBPS } 1 \mathrm{~m}^{3} \\
\text { (f'c }=25 \mathrm{Mpa})\end{array}$ & 329,94 & 328,01 & 950,53 & 422,22 & 177,16 & 4,22 \\
\hline
\end{tabular}

Ket: PB = Beton yang menggunakan pasir besi sebagai agregat halus; PBPS = Beton yang menggunakan pasir besi + pasir sungai sebagai agregat halus.

\subsection{Slump Flow Test}

Untuk mengetahui kemudahan dalam pengerjaan (workability) suatu pekerjaan beton, maka perlu diuji kelecakan dari adukan beton SCC. Untuk mengetahui kelecakan dari beton SCC adalah dengan cara menguji nilai slump flow dari campuran SCC yang telah dibuat, dimana hasil pengujian nilai $\mathrm{T}_{50 \mathrm{~cm}}$ dan slump flow pada penelitian ini diperlihatkan pada Tabel 3 dan Gambar 4 dibawah.

Tabel 3. Hasil Pengujian Slump Flow Tiap Rancangan Campuran Beton SCC

\begin{tabular}{cccc}
\hline No. & Jenis Pengujian & $\mathrm{T}_{50}$ (detik) & Slump Flow $(\mathrm{cm})$ \\
\hline 1. & Beton SCC - PB $\left(\mathrm{f}_{\mathrm{c}}=25 \mathrm{MPa}\right)$ & 3.58 & 70,55 \\
\hline 2. & Beton SCC - PBPS $\left(\mathrm{f}_{\mathrm{c}}=25 \mathrm{MPa}\right)$ & 4,25 & 71,49 \\
\hline
\end{tabular}

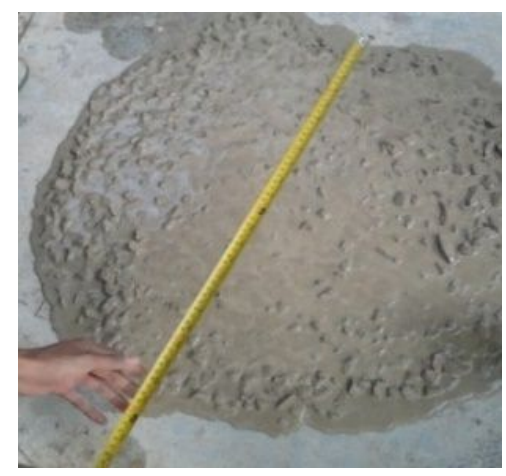

Gambar 4. Pengujian nilai Slum Flow

Dari hasil pengujian nilai slump flow pada Tabel 3 maupun Gambar 4 terlihat bahwa, waktu pengujian karakteristik beton melalui uji kelecakan menunjukkan kecapatan aliran campuran beton SCC sudah memenuhi target pengujian dimana nilai T50 telah memenuhi stándar waktu yang diisyaratkan dengan diameter rata-rata slump flow cukup baik, hal ini menunjukkan bahwa beton SCC yang dibuat akan memenuhi ruang cetakan dengan baik, tanpa diperlukan alat pemadatan atau vibrator.

\subsection{Kuat Tekan Beton SCC (f'c)}

Tabel 4 dan Tabel 5 di bawah, memperlihatkan data hasil pengujian kuat desak beton untuk variasi pemakain $100 \%$ pasir besi dan kombinasi $50 \%$ pasir besi ditambah $50 \%$ pasir sungai. Terlihat pada kedua tabel bahwa variasi nilai kuat tekan beton SCC pada umur 28 
hari untuk variasi $50 \%$ pasir besi ditambah $50 \%$ pasir sungai lebih besar bila dibandingkan dengan variasi pemakaian $100 \%$ pasir besi, hal ini dikarenakan adanya pasir sungai dengan butiran yang sedikit lebih halus dari pasir besi sehingga mengisi pori pada beton SCC dan membuat beton SCC menjadi lebih padat dan hal ini menigkatkan nilai kuat tekan beton, disamping itu pula karena pasir besi juga mempunyai berat jenis yang lebih besar dari pada pasir sungai.

Tabel 4. Hasil Pemeriksaan Kuat Tekan Beton SCC PB

\begin{tabular}{ccccccccc}
\hline \multirow{2}{*}{ No. } & Umur & Berat & Slump & Luas (A) & f & Beban (P) & f'c = P/A & f'ci = fc/k \\
\cline { 2 - 8 } & $($ hari $)$ & $(\mathbf{k g})$ & $(\mathbf{c m})$ & $\left(\mathbf{c m}^{2}\right)$ & $(\mathbf{k N})$ & $(\mathbf{k g})$ & $\left(\mathbf{k g} / \mathbf{c m}^{2}\right)$ & $(\mathbf{M p a})$ \\
\hline 1 & 3 & 12,113 & 70.55 & 176.71 & 440.00 & $44,852.19$ & 253.81 & 13.46 \\
2 & 7 & 12,135 & 70.55 & 176.71 & 420.00 & $42,813.46$ & 242.27 & 19.23 \\
3 & 28 & 12,135 & 70.55 & 176.71 & 590.00 & $60,142.71$ & 340.34 & 28.27 \\
\hline
\end{tabular}

Tabel 5. Hasil Pemeriksaan Kuat Tekan Beton SCC PBPS

\begin{tabular}{ccccccccc}
\hline \multirow{2}{*}{ No. } & Umur & Berat & Slump & Luas $(\mathbf{A})$ & f & Beban P & f'c = P/A & f'ci = fc/k \\
\cline { 2 - 9 } & $($ hari $)$ & $(\mathbf{k g})$ & $(\mathbf{c m})$ & $\left(\mathbf{c m}^{2}\right)$ & $(\mathrm{kN})$ & $(\mathbf{k g})$ & $\left(\mathbf{k g} / \mathbf{c m}^{2}\right)$ & $(\mathbf{M p a})$ \\
\hline 1 & 3 & 12,135 & 71.49 & 176.71 & 450.00 & $45,871.56$ & 259.58 & 14.42 \\
2 & 7 & 12,255 & 71.49 & 176.71 & 410.00 & $41,794.09$ & 236.51 & 20.57 \\
3 & 28 & 12,255 & 71.49 & 176.71 & 690.00 & $70,336.39$ & 398.02 & 30.96 \\
\hline
\end{tabular}

Dari tabel-tabel di atas terlihat bahwa nilai kuat tekan beton untuk kedua variasi penggunaan pasir besi dalam campuran beton SCC mengalami kenaikan $20 \%$ sampai $40 \%$ di setiap umur betonnya, hal ini dikarenakan kekuatan beton terus mengalami penigkatan selama masa perawatan. Hasil kuat tekan beton pada umur 28 hari untuk variasi kombinasi pasir besi dan pasir sungai menigkat sebesar $30.96 \mathrm{Mpa}$ atau sekitar $40 \%$ dari kuat tekan sebelumnya, sedangkan untuk variasi penggunaan $100 \%$ pasir besi nilai kuat tekan beton saat umur 28 hari hanya sebesar 28.27 Mpa.

Berikut pada Gambar 5 diperlihatkan grafik perbandingan kekuatan beton untuk kedua variasi penggunaan pasir besi dalam campuran beton SCC serta pada Gambar 6 memperlihatkan pola keruntuhan pada benda uji setelah dilakukan uji kuat tekan.

Pada Gambar 5 memperlihatkan bahwa pada kedua variasi penggunaan pasir besi untuk campuran beton SCC mengalami penigkatan kekuatan selama masa perawatan. Namun, terdapat perbedaan penigkatan kekuatan beton untuk kedua variasi campuran beton SCC yang menggunakan pasir besi sebagai pengganti material halus, dimana variasi $100 \%$ pemakaian pasir besi kuat tekan rata-rata beton saat umur 28 hari hanya mencapai nilai kuat tekan sebesar 28.27 Mpa sedangkan pada variasi 50\% pasir besi ditambah 50\% pasir sungai nilai kuat tekan beton rata-rata saat umur 28 hari lebih tinggi dengan nilai sebesar 30.96 Mpa. Hal ini dikarenakan kombinasi antara pasir sungai dan pasir besi mampu menutup rongga pada beton sehingga membuat beton menjadi semakin padat. 


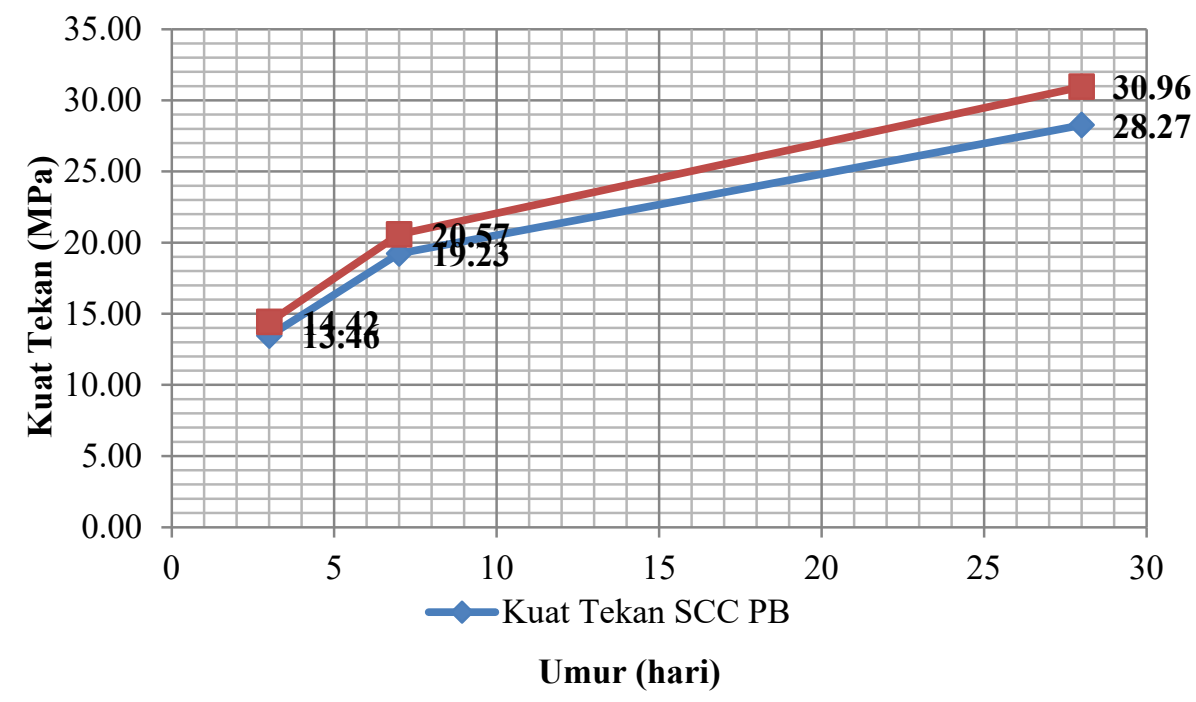

Gambar 5. Grafik kuat tekan beton untuk dua variasi penggunaan pasir besi

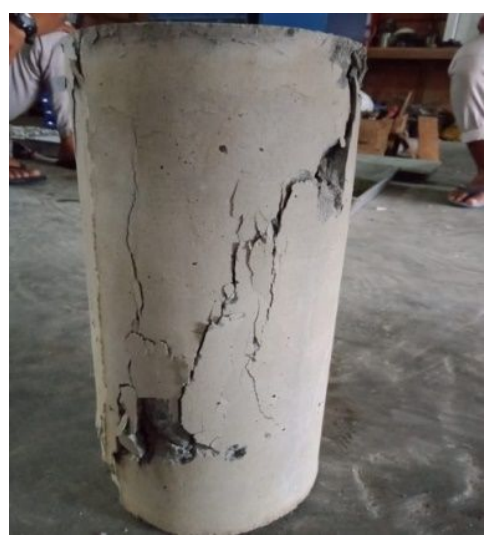

Gambar 6. Pola keruntuhan pada benda uji

Pada Gambar 7 di bawah ini juga memperlihatkan bagaimana persentase kenaikan kuat tekan beton terhadap kuat tekan beton umur 28 hari untuk kedua variasi penggunaan pasir besi pada beton SCC yang menggunakan pasir besi sebagai subtitusi pengganti agregat halus. Pada Gambar 7 terlihat bahwa setiap kenaikan umur beton maka nilai kuat tekan beton akan terus bertambah, dimana kenaikan nilai kuat tekan beton dari umur umur 3 hari ke umur 7 hari mengalami penigkatan kekuatan sebesar 20\% dan dari umur 7 hari ke umur 28 hari nilai kuat tekan beton mengalami penigkatan sebesar $40 \%$, hal ini dikarenakan semakin bertambah umur beton maka nilai kuat tekannyapun akan bertambah. 


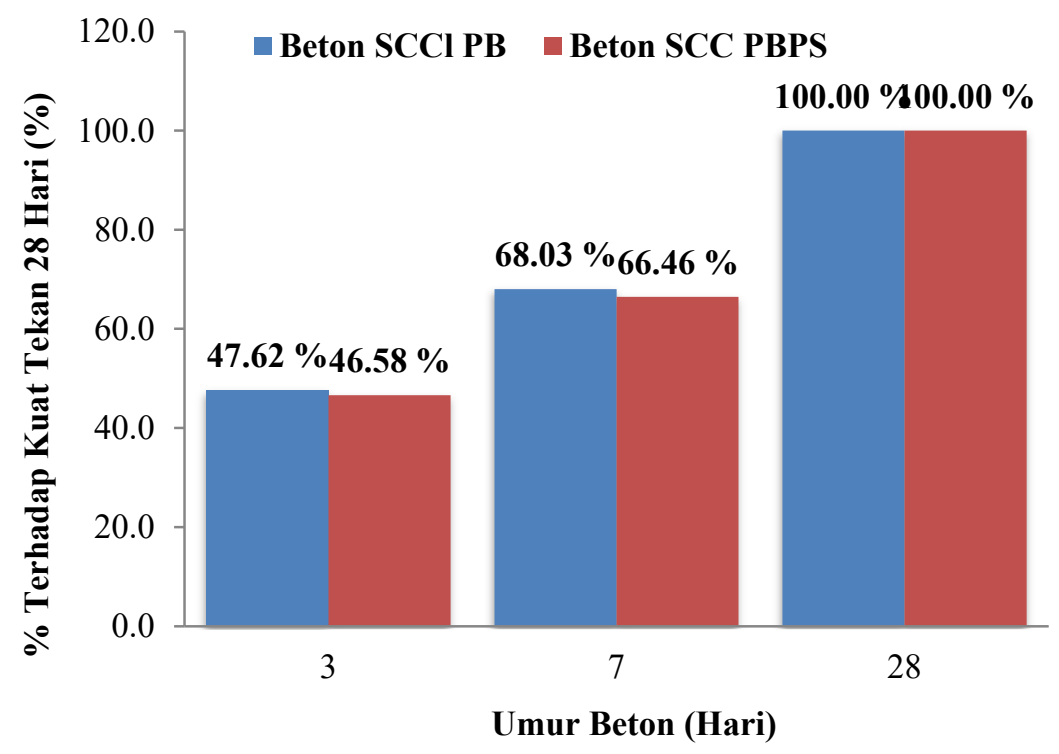

Gambar 7. Diagram Persentase Kuat Tekan Beton Terhadap Kuat Tekan Beton Umur 28 Hari

\section{KESIMPULAN}

Hasil pemeriksaan karakteristik agregat halus pasir besi memperlihatkan bahwa nilai dari modulus kehalusan adalah sebesar 2,55 nilai ini telah memenuhi spesifikasi dan masuk kategori pasir agak kasar yakni berada pada zone 2, dengan berat jenis semu sebesar 4,47, berat jenis kering sebesar 4,35, berat jenis SSD sebesar 4,39, Penyerapan air sebesar $1,20 \%$, dan Send Equivalen ialah $97 \%$, dan angka atau nilai dari hasil pengujian karakteristik ini semuanya telah memenuhi standar nilai yang diisyaratkan oleh American Society for Testing Material(ASTM).

Hasil uji dan analisa data kuat tekan beton SCC yang memakai pasir besi sebagai agregat halus dengan 2 variasi campuran beton diperoleh :

- Kuat tekan rata-rata beton SCC dengan variasi campuran beton $100 \%$ pasir besi untuk umur beton 3, 7 dan 28 hari hari adalah 13.46 Mpa, 19,23 Mpa dan 28,27 Mpa, hal ini menunjukan bahwa nilai kuat tekan beton akan semakin bertambah seiring dengan bertambahnya umur beton.

- Nilai kuat tekan rata-rata beton SCC dengan variasi campuran beton $50 \%$ pasir besi dan 50\% pasir sungai untuk umur beton 3, 7 dan 28 hari adalah 14,42 MPa, 20,57 MPa dan 30,96 MPa, dari nilai tersebut terlihat bahwa variasi penggunaan pasir besi dan pasir sungai dalam campuran beton Self Compacting Concrete semakin baik dalam peningkatan nilai kuat tekan beton hal ini dikarenakan kehalusan dari pasir sungai mampu mengisi pori dari pada beton sehingga beton SCC yang menggunakan variasi campuran pasir besi dan pasir sungai ini menjadi semakin padat dan hal ini membuat nilai kuat tekan betonnya semakin tinggi.

Merujuk hasil penelitian ini maka disarankan untuk penelitian kedepannya dapat dikembangkan untuk disain benda uji yang lebih besar seperti saluran drainase beton pracetak ( $U$-Ditch) dengan metode SCC, yang memanfaatkan pasir besi sebagai agregat halus. Sehingga dapat diketahui seberapa besar kontribusi penggunaan pasir besi tersebut pada saluran drainase pracetak (U-Ditch) dalam memikul beban lentur. 


\section{DAFTAR PUSTAKA}

ASTM. (2003). Manual of Aggregate and Concrete Testing. Volume 04.02. US and Canada. Mannual Book of ASTM.

Astuti, R. K. (2017). Pengaruh Perbedaan Bentuk Penampang Spesimen erhadap Hubungan Tegangan dan Regangan pada Beton High Volume Fly Ash Self Compacting Concrete (HvfaScc). Program Studi Teknik Sipil, Universitas Sebelas Maret (UNS).

Astuti, R. K., Budi, A. S., \& Sangadji, S. (2018). Pengaruh Perbedaan Bentuk Penampang Spesimen Terhadap Hubungan Tegangan Dan Regangan Pada Beton High Volume Fly Ash Self Compacting Concrete (HVFA-SCC). Matriks Teknik Sipil, 6(1).

Badan Standardisasi Nasional. (1990). SNI 03-1974-1990. Metode Pengujian Kuat Tekan Beton. In Badan Standarisasi Nasional, Jakarta.

Badan Standarisasi Nasional. (2000). SNI 03-2834-2000, Tata Cara Pembuatan Rencana Campuran Beton Normal.

Badan Standarisasi Nasional. (2011). SNI 2493:2011 Tata cara pembuatan dan perawatan benda uji beton di laboratorium.

Korua, A. M., Dapas, S. O., \& Handono, B. D. (2019). Kinerja High Strength Self Compacting Concrete Dengan Penambahan Admixture "Beton Mix" Terhadap Kuat Tarik Belah. Jurnal Sipil Statik, $7(10)$.

Miza, S. D. S., Wallah, S. E., \& Mondoringin, M. R. (2019). Perilaku Mekanis High Strength Self Compacting Concrete Dengan Penambahan Admixture "Beton Mix" Terhadap Kuat Tarik Lentur. JURNAL SIPIL STATIK, Ұ(11).

Ngudiyono, N., Merdana, I. N. M., Mahmud, F., \& Fajrin, J. (2021). Kajian Eksperimental Kuat Lekat Tulangan Beton Memadat Sendiri (Self Compaction Concrete). Prosiding SAINTEK, 3, 328338.

Nicolaas, S., \& Slat, E. N. (2019). Pemanfaatan Beton Pemadatan Mandiri (Self Compacting Concrete) Sebagai Balok Struktur Dengan Menggunakan Agregat Lokal. Jurnal Integrasi, 11(2), 81-85.

Safarizki, H. A. (2017). Pengaruh Bahan Tambah Serbuk Bata Dan Serat Fiber Pada Self Compacting Concrete (Scc). Jurnal Ilmiah Teknosains, 3(2). 